\title{
Nitrogen Release Pattern From Organic Manures Applied to an Acid Soil
}

\author{
A. Vel Murugan ${ }^{1} \&$ T. P. Swarnam ${ }^{1}$ \\ ${ }^{1}$ Central Agricultural Research Institute, Indian Council of Agricultural Research, Port Blair-744 101, India \\ Correspondence: A. Vel Murugan, Central Agricultural Research Institute, Indian Council of Agricultural \\ Research, Port Blair-744 101, India. E-mail: vels_21@yahoo.com
}

\author{
Received: March 5, 2013 Accepted: April 7, 2013 Online Published: May15, 2013 \\ doi:10.5539/jas.v5n6p174 URL: http://dx.doi.org/10.5539/jas.v5n6p174
}

\begin{abstract}
Study of nitrogen release pattern from organic manures is very essential to ensure nitrogen supply in adequate quantity and at proper time to crop plants in an acid soil. A laboratory incubation experiment was conducted to determine the nitrogen release pattern from vermicompost (V.C), poultry manure (P.M), neem, inorganic fertilizer (I.O) and its combinations applied to an acid soil at two different rates. Cumulative nitrogen mineralization was significantly higher throughout the incubation period for I.O, V.C+P.M and I.O+V.C while it was two weeks after incubation for V.C and V.C+Neem due to the inhibitory effect of neem on nitrification. The results indicated a significant increase in the rate of $\mathrm{N}$ mineralization in the first one week in which the highest rate of $3.36 \mathrm{mg} \mathrm{N}$ day ${ }^{-1}$ was observed for inorganic fertilizer and thereafter it slowed down. V.C followed by V.C+Neem recorded higher rate of $\mathrm{N}$ mineralization of 0.24 and $0.23 \mathrm{mg} \mathrm{day}^{-1}$ respectively, from $48^{\text {th }}$ days after incubation. V.C+Neem at 120 $\mathrm{kg} \mathrm{N}$ equivalent ha ${ }^{-1}$ recorded the highest ammonia content of $42.1 \%$ to total available $\mathrm{N}$ while V.C+P.M recorded higher nitrate content of $82.3 \%$ at the end of the incubation period. Positive correlation between initial nitrogen and total mineralized $\mathrm{N}$ from the manures and fertilizers $\left(\mathrm{R}^{2}=0.563\right)$ was observed. Furthermore, addition of organic manures resulted in increase in soil $\mathrm{pH}$ where as inorganic fertilizer showed a slight decrease (5.73) than control (5.78).
\end{abstract}

Keywords: $\mathrm{N}$ mineralization, organic manures, acid soil

\section{Introduction}

Ever since its introduction in the 1960's modern agricultural technologies involving the use of high yielding varieties, chemical fertilizers and pesticides among others have increased the food grain production tremendously across the world. Chemical fertilizers have played a predominant role in green revolution and initially the results were impressive. But, in the subsequent years unfavorable effects such as decreasing productivity, huge neglected areas of poor soils and water resources, and environmental impact have emerged. In addition the readily available forms of nutrients in inorganic fertilizers have pushed the traditional important sources of nutrients especially organic manures of different origin into a decline (Nagarajah, 1988). As agriculture became more settled, with a permanent land base, and as cultivation practices intensified, soil fertility became severely depleted. Ironically, this same period also marked the beginning of a massive global loss of soil organic carbon (SOC) associated with the rapid expansion of agriculture onto grassland and forest soils (Manna, Ghosh, \& Acharya, 2003).

Organic matter plays a prominent role in increasing the level of soil fertility and sustaining the productivity of soils. Simultaneously rising costs of chemical fertilizers has further focused attention on recycling of plant nutrients through organic materials. Thus, the potential of organic manure use either alone or in combination with chemical fertilizers in crop production has received world wide attention. The importance of organic manure as a source of humus and plant nutrients to improve the soil fertility and soil health has been well established (Larson \& Clapp, 1984; Doran \& Parkin, 1994; Sudha \& Chandini, 2003). In addition, the effect of different organic manures and its combinations on vegetable crops such as okra, tomato, onion etc., are widely studied (Masciandaro, Ceccanti, \& Garcia, 1997; Buckerfield \& Webster, 1998; Atiyeh et al., 2000; Bairwa, 2009; Islam et al., 2011; Kumar, Gowda, Shetty, \& Karthik, 2011). In recent times, reports on organic manure as a source of plant nutrients for field crops particularly as an alternative to chemical fertilizers in rice cultivation is also increasing (Banik et al., 2006; Siavoshi, Nasiri, \& Laware, 2011). 
Undoubtedly organic manures have greater role to play in sustaining the agricultural production in any island agroecosystems due to its relative isolation and fragile ecosystem. In this context, it is imperative to study the effect of different organic manures on soil fertility of Andaman Islands, India. In recent times, inorganic input use is increasing particularly in vegetable production as these crops are more profitable. However due to the humid and high rainfall condition the nutrient loss from applied fertilizers is high leading to low input use efficiency and low productivity. The very limited scope available for area expansion under agriculture coupled with the low input use necessitates the importance of sustainable land management practices to increase the agricultural production. Such practices essentially include the use of different organic manures alone or in combination with inorganic fertilizers for which there is amble scope exists in these islands.

At the same time the suitability of organic materials as fertilizer depends to a great extent on its rapidity of mineralization and liberating the nutrients present in them (Weeraratna, 1979). Mineralization of nitrogen is the transformation of nitrogen from organic into inorganic form and the immobilization is the reversal of the process. These processes are biochemical in nature and are mediated through the activities of microorganisms (Bartholomow, 1965). The resulting effects of these two processes are expressed as net mineralization or net immobilization which decides the nitrogen supply to the growing crops. At the same time the mineralization immobilization turnover in soil is affected by soil properties such as temperature, soil moisture, $\mathrm{pH}, \mathrm{C} / \mathrm{N}$ ratio apart from total $\mathrm{N}$ and lignin content of the organic materials (Pathak \& Sarkar, 1994). Besides, addition of nitrogen in proper dose at proper time is very essential for increasing the crop productivity. Thus understanding the process of mineralization and nitrogen availability in different organic manures, inorganic fertilizers and their combination at different doses are essential to avoid nutrient deficiency and successful crop production.

The investigations reported in this paper were carried out to examine the pattern of $\mathrm{NH}_{4}{ }^{+}-\mathrm{N}$ and $\mathrm{NO}_{3}{ }^{2-}-\mathrm{N}$ release from organic manures and in combination with inorganic fertilizers in an acid soil under humid tropical island climate. It is intended to evaluate the organic sources of nutrients supply as an alternate to inorganic fertilizers in a not so intensive cultivation system where soil acidity is also a problem.

\section{Materials and Methods}

\subsection{Study Area}

The tropical island of Andaman and Nicobar lie extending from north to south in the Bay of Bengal, at a distance of $1200 \mathrm{~km}$ from the Indian mainland. Out of the total geographical area of $8249 \mathrm{~km}^{2}$, only $4.8 \%$ is cultivated whereas the rest of the area is under forest cover (DES, 2009). The Islands receive high rainfall of around 3100 $\mathrm{mm}$ from May to November as a result only rice is grown in valley areas and vegetables are mainly grown during the dry season starting from December to April. The soils are mostly acidic due to leaching of metal cations, medium to high in organic carbon content and the terrain is undulating (Ganeshamurthy, Dinesh, Ravisankar, Nair, \& Ahlawat, 2002).

\subsection{Experimental Design}

An incubation study was conducted at Central Agricultural Research Institute, Port Blair, Andaman Islands, India to determine the nitrogen release pattern in a Typic Tropofluvents soil having $\mathrm{pH} 5.85$ due to the addition of organic manures and inorganic fertilizers. Surface soil $(0-30 \mathrm{~cm})$ from cultivated land was collected, shade dried, processed and analyzed for the required soil fertility parameters following standard procedures (Jackson, 1973). The same soil was used for incubation experiment. The soil was found to be medium in organic carbon (0.65), low in available nitrogen $\left(275 \mathrm{~kg} \mathrm{ha}^{-1}\right)$, medium in phosphorus $\left(16.1 \mathrm{~kg} \mathrm{ha}^{-1}\right)$ and low in potassium $\left(146 \mathrm{~kg} \mathrm{ha}^{-1}\right)$.

Three major organic manures such as vermicompost (V.C), poultry manure (P.M) and neem cake were used in combination with inorganic fertilizers (I.O). The treatments consisted of control (T1), $120 \mathrm{~kg} \mathrm{~N}$ ha $^{-1}$ through V.C (T2), $90 \mathrm{~kg} \mathrm{~N} \mathrm{ha}^{-1}$ through V.C (T3), $60 \mathrm{~kg} \mathrm{~N} \mathrm{ha}^{-1}$ through V.C (T4), $120 \mathrm{~kg} \mathrm{~N} \mathrm{ha}^{-1}$ through V.C+P.M (T5), $90 \mathrm{~kg}$ $\mathrm{N} \mathrm{ha}^{-1}$ through V.C+P.M (T6), $60 \mathrm{~kg} \mathrm{~N}^{-1}$ through V.C+P.M (T7), $120 \mathrm{~kg} \mathrm{~N}^{-1}{ }^{-1}$ through I.O (T8), $60 \mathrm{~kg} \mathrm{~N}^{-1}$ through I.O (T9), $120 \mathrm{~kg} \mathrm{~N}^{-1}$ through V.C+ I.O (T10), $90 \mathrm{~kg} \mathrm{~N}^{-1}$ through V.C+I.O (T11), $60 \mathrm{~kg} \mathrm{~N}^{-1}$

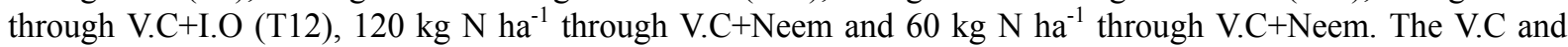
P.M combinations were included to study its potential to supply the crop with adequate $\mathrm{N}$ during its early growth stages. The neem treatment was incorporated to assess its nitrification inhibiting effect.

The general recommended fertilizer dose of $120,70,60 \mathrm{~kg} \mathrm{ha}^{-1}$ of NPK for the major vegetables grown in these islands viz. okra, brinjal, chilies and cole crops was taken as a reference value to estimate the quantity of organic manures required based on $\mathrm{N}$ equivalent basis. Inorganic nutrients were supplied through urea, single super phosphate and muriate of potash. The nutrient composition of the manures indicated that P.M has higher nutrient content than V.C. On an average P.M contains $2.2,0.8$ and $0.97 \%$ of N, P and K while V.C contains 1.3, 0.69 and 
$0.82 \%$ of $\mathrm{N}, \mathrm{P}$ and $\mathrm{K}$.

\subsection{Incubation Leaching Study}

Nitrogen mineralization was studied using specially fabricated polypropylene bottles. The bottom portion of the bottles were removed and placed in side the bottle in upside down position after making small holes to facilitate aeration and leaching. The mouth of the bottles was plugged with rubber cork attached with $15 \mathrm{~cm}$ long drainage pipes. A round piece of nylon cloth was placed in side the bottles above which a pad of glass wool of $2 \mathrm{~cm}$ thickness was placed. 100 gram soil and 50 gram acid washed quartz sand were moistened using distilled water and mixed thoroughly. This moistening treatment was given to get homogenous mixture and to prevent particle size segregation during transfer to leaching bottle. The soil quartz mixture was then transferred to the leaching bottles above which again some glass wool was placed to avoid water splash while adding chemicals or water. There were 42 bottles to accommodate 14 treatments and 3 replications. These bottles were placed on a specially fabricated stand and incubated at room temperature with field capacity moisture level. Leaching was performed by adding $100 \mathrm{ml}$ of $0.01 \mathrm{M} \mathrm{CaCl}_{2}$ solutions in $20 \mathrm{ml}$ increment followed by $25 \mathrm{ml}$ of N free nutrient solution $\left(\mathrm{CaSO}_{4} \cdot 2 \mathrm{H}_{2} \mathrm{O} 2\right.$ millimoles $+\mathrm{MgSO}_{4}+\mathrm{Ca}\left(\mathrm{H}_{2} \mathrm{PO}_{4}\right)_{2} 5$ millimoles $+\mathrm{K}_{2} \mathrm{SO}_{4} 2.5$ millimoles $)$.

The soil column in the leaching bottles was leached after $0,2,4,9,16,23,34,48,62,76,90$ and $104^{\text {th }}$ days after incubation and the leachate was collected in a separate polyethylene bottles and the volume was determined using a measuring cylinder. Ammonia and nitrate nitrogen content in the leachate was determined using a nitrogen distillation system (Kelplus). The results were expressed as $\mathrm{mg} \mathrm{kg}^{-1}$ (mg of nitrogen per kg soil). After every leaching field capacity moisture level was maintained until the next leaching. Similar set of leaching bottles were kept separately for the periodical monitoring of soil $\mathrm{pH}$. The mean monthly minimum and maximum temperature during the experimental period was $22.1^{\circ} \mathrm{C}$ and $32.5^{\circ} \mathrm{C}$, respectively. The relative humidity was high $(82.3 \%)$ with less deviation (2.8\%) typical to the tropical island ecosystem.

It is both conventional and expedient to divide the Method section into labeled subsections. These usually include a section with descriptions of the participants or subjects and a section describing the procedures used in the study. The latter section often includes description of (a) any experimental manipulations or interventions used and how they were delivered-for example, any mechanical apparatus used to deliver them; (b) sampling procedures and sample size and precision; (c) measurement approaches (including the psychometric properties of the instruments used); and (d) the research design. If the design of the study is complex or the stimuli require detailed description, additional subsections or subheadings to divide the subsections may be warranted to help readers find specific information.

Include in these subsections the information essential to comprehend and replicate the study. Insufficient detail leaves the reader with questions; too much detail burdens the reader with irrelevant information. Consider using appendices and/or a supplemental website for more detailed information.

\subsection{Statistical Analysis}

Analyses of variance were done on all soil parameters, the means of parameters were grouped for comparisons, and differences were separated by least significant difference (LSD) using SAS (SAS Institute, Inc. Cary, NC, USA 1990). Significant differences were determined at $\mathrm{P} \leq 0.05$.

\section{Results}

\subsection{Cumulative N Release}

The $\mathrm{NH}_{4}{ }^{+}, \mathrm{NO}_{3}{ }^{2-}$ and total available nitrogen content of the soil depend on the balance between the factors which influence the concentration of these nutrients. The nature of materials and condition of soil are the two most important factors affecting the $\mathrm{N}$ release. In the present study it was observed that manures and fertilizers had significantly increased the concentration of mineral nitrogen $\left(\mathrm{NH}_{4}{ }^{+}+\mathrm{NO}_{3}{ }^{2-}\right.$ nitrogen) in soil due to net mineralization during the incubation period (Figure 1). Evidently the amount of $\mathrm{N}$ released in to the soil increased with increase in the rate of application of manures and fertilizers. However, amount of release of nitrogen from applied manures and fertilizers varied among the treatments and at different time periods. This was in agreement with the similar reports of Yadvinder Singh, Bijay Singh, and Khind (1992). 


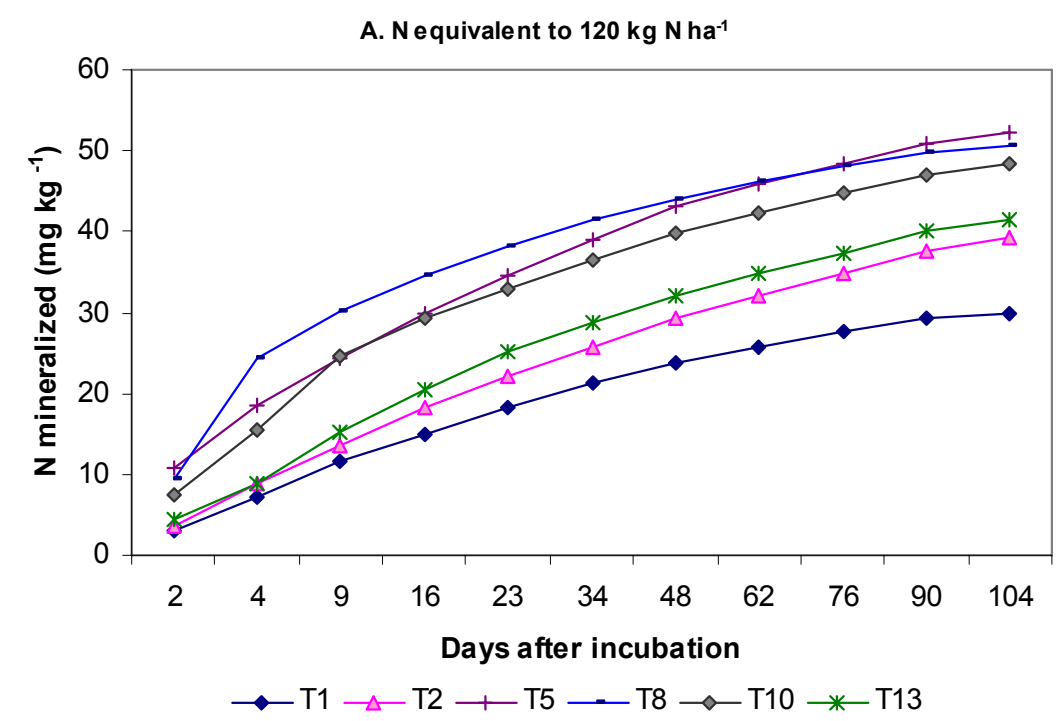

B. $\mathrm{N}$ equivalent to $60 \mathrm{~kg} \mathrm{~N} \mathrm{ha}^{-1}$

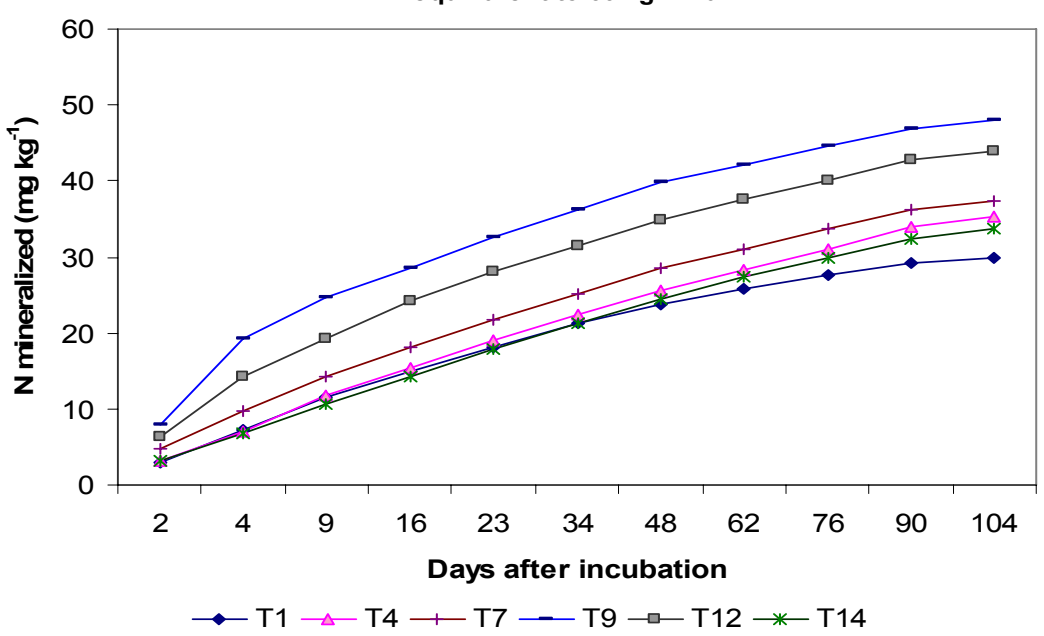

Figure 1. Cumulative $\mathrm{N}$ mineralization $\left(\mathrm{mg} \mathrm{kg}^{-1}\right)$ during incubation

Significant increase in the cumulative $\mathrm{N}$ mineralization through out the incubation period was observed for inorganic fertilizers, V.C+P.M and I.O+V.C while V.C and V.C+Neem treatments showed significant increase over control only from 16th day onwards. Among the treatments which received $120 \mathrm{~kg} \mathrm{~N}$ equivalent $\mathrm{ha}^{-1}$, V.C+P.M recorded the highest net $\mathrm{N}$ mineralization of $52.17 \mathrm{mg} \mathrm{kg}^{-1}$ which was at par with inorganic fertilizer and I.O+V.C at the same rate (Figure 1A). Though the net N mineralization in V.C+P.M was lower than the inorganic treatments in the initial 60 days, but it overtook to record the highest cumulative $\mathrm{N}$ mineralization at the end of the incubation period. Rayar (1984) also reported an increase in available $\mathrm{N}$ when poultry manure and FYM were applied to soil.

Similarly, manures and inorganic fertilizer treatments at $60 \mathrm{~kg} \mathrm{~N}$ equivalent ha- 1 also significantly increased the net $\mathrm{N}$ mineralization. Among the treatments inorganic fertilizer application at $60 \mathrm{~kg} \mathrm{~N}$ ha ${ }^{-1}$ recorded significantly higher net $\mathrm{N}$ mineralization through out the incubation period (Figure 1B). This was followed by I.O+V.C, V.C+P.M and V.C at the same rate. At the same time V.C+Neem recorded slow rate of N mineralization till 34 DAI, there after it increased. But the cumulative $\mathrm{N}$ mineralized at the end of the incubation period was lower than inorganic and poultry manure combinations. This indicated the inhibitory effect of neem on nitrification as a consequence $\mathrm{N}$ was released slowly but for a longer period of time. 


\subsection{Rate of $N$ Release}

During the mineralization process ammonia is first released into the soil on which the nitrification bacteria acts and oxidizes into nitrate form. More ammonium tends to accumulate if the nitrification process is inhibited on the other hand ammonium content decreases with the increase in the nitrate form (Bartholomow, 1965; Power \& Papendick, 1985). Application of manures and fertilizers had significantly increased the rate of $\mathrm{N}$ mineralization $\left(\mathrm{NH}_{4}{ }^{+}+\mathrm{NO}_{3}{ }^{2-}\right)$ in the first one week of incubation over the control. In general, with in a week after incubation it reached the peak thereafter it slowed down in all the treatments though at different rate. During the initial one week the highest rate of mineralization was observed for inorganic fertilizer $\left(3.36 \mathrm{mg} \mathrm{day}{ }^{-1}\right)$ followed by V.C+P.M and I.O+V.C at $120 \mathrm{~kg} \mathrm{~N}$ equivalent $\mathrm{ha}^{-1}$ (Figure 2A). Thereafter the rate of mineralization from inorganic treatments slowed down where as V.C+P.M maintained the higher rate of mineralization $\left(0.91 \mathrm{mg} \mathrm{day}^{-1}\right)$ upto $48^{\text {th }}$ DAI. Though V.C treatment recorded relatively low rate of mineralization than other treatments, interestingly from $48^{\text {th }}$ DAI onwards it recorded higher rate of $\mathrm{N}$ mineralization $\left(0.24 \mathrm{mg}^{-1} \mathrm{day}^{-1}\right)$ followed by V.C+Neem $\left(0.23 \mathrm{mg} \mathrm{day}^{-1}\right)$ till the end of the incubation period. Similar trend was observed at $60 \mathrm{~kg} \mathrm{~N}$ equivalent ha ${ }^{-1}$ as well (Figure $2 \mathrm{~B}$ ).

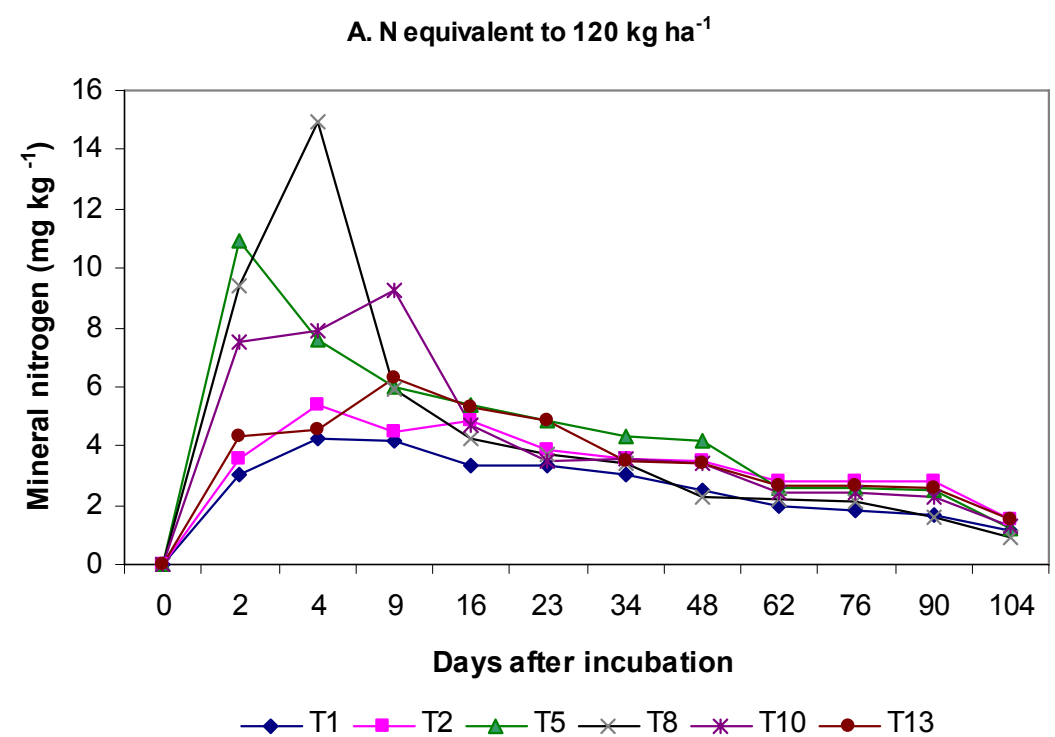

B. N equivalent to $60 \mathrm{~kg} \mathrm{ha}^{-1}$

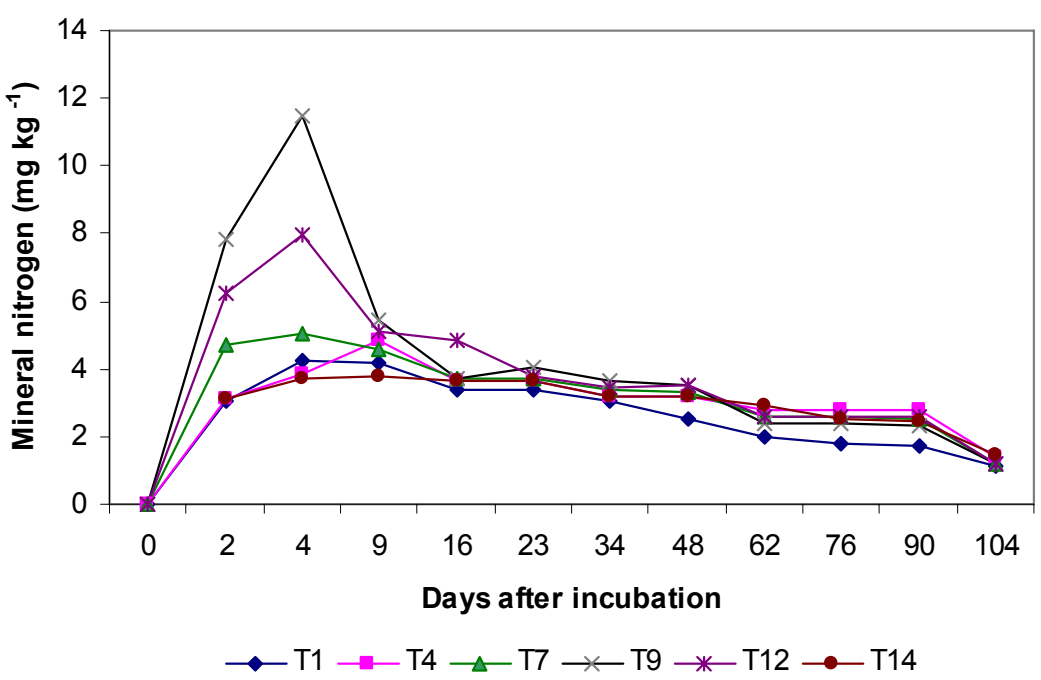

Figure 2. Rate of $\mathrm{N}$ mineralization in different treatments 
With respect to the release of $\mathrm{NH}_{4}^{+} \mathrm{N}$ the results indicated that in all the treatments except V.C+Neem, it significantly increased over the control during the first two weeks. But, the rates of increase of $\mathrm{NH}_{4}^{+} \mathrm{N}_{\text {in }}$ different treatments varied with the lowest recorded for V.C+Neem treatment. Similarly manures and inorganic fertilizer treatments significantly increased the rate of $\mathrm{NO}_{3}{ }^{2-} \mathrm{N}$ content during incubation indicating its higher availability to crops. The rate of nitrification was by and large followed the trend of release of ammonia from organic and inorganic fertilizers. Among the treatments inorganic fertilizers recorded the highest nitrification during the initial one week after incubation whereas V.C+Neem treatment was observed to be the lowest.

\subsection{Available Nitrogen}

The total available nitrogen (mineral $\mathrm{N}$ ) includes initial mineral nitrogen and nitrogen mineralized during the incubation period of 104 days of both $\mathrm{NH}_{4}{ }^{+}$and $\mathrm{NO}_{3}{ }^{2-}$ form. Among these two forms of $\mathrm{N}$, nearly $68 \%$ of the total available $\mathrm{N}$ was found to be in the form of nitrate indicating the faster nitrification process and aerobic condition. Among the treatments V.C + Neem at $120 \mathrm{~kg} \mathrm{~N}$ equivalent ha ${ }^{-1}$ recorded highest ammonia content of $42.1 \%$ to total available N. Alternatively, higher nitrate content of $82.3 \%$ to total available $\mathrm{N}$ was observed for V.C+P.M treatment.

The total available $\mathrm{N}$ status decreased with the corresponding decrease in the rate of application of manures and fertilizers. I.O+V.C recorded the highest available $\mathrm{N}$ of $97 \mathrm{mg} \mathrm{kg}^{-1}$ followed by V.C+P.M and V.C+Neem at 120 $\mathrm{kg} \mathrm{N}$ equivalent ha ${ }^{-1}$. Significantly higher total available nitrogen was recorded in all the treatments except V.C and V.C+Neem at $60 \mathrm{~kg} \mathrm{~N}$ equivalent ha ${ }^{-1}$ due to slow rate of mineralization. It was also observed that the amount of available $\mathrm{N}$ from V.C combination with either P.M or neem has tremendously increased over the sole application of V.C alone at any rate. Amanullah (2007) also showed that poultry manure can increase the available $\mathrm{N}$ progressively and make it available to the plants for a longer period of time with other manures.

The results showed that initial $\mathrm{N}$ content of the manures and inorganic fertilizer had significant influence on the rate of $\mathrm{N}$ release as well as the total $\mathrm{N}$ mineralized though the magnitude varied among the treatments. There was a positive agreement between initial nitrogen content and available $\mathrm{N}$ from the manures and inorganic fertilizer $\left(\mathrm{R}^{2}=0.563\right)$. It was observed from Figure 3 that the total available nitrogen steadily increased with the increase in the initial $\mathrm{N}$ and reached the maximum at $45 \mathrm{mg} \mathrm{kg}^{-1}$ of initial $\mathrm{N}$ content. There after the total available $\mathrm{N}$ had decreased exhibiting a bell shape of the relationship curve. This was in agreement with the finding of Martin Burger and Venterea (2007).

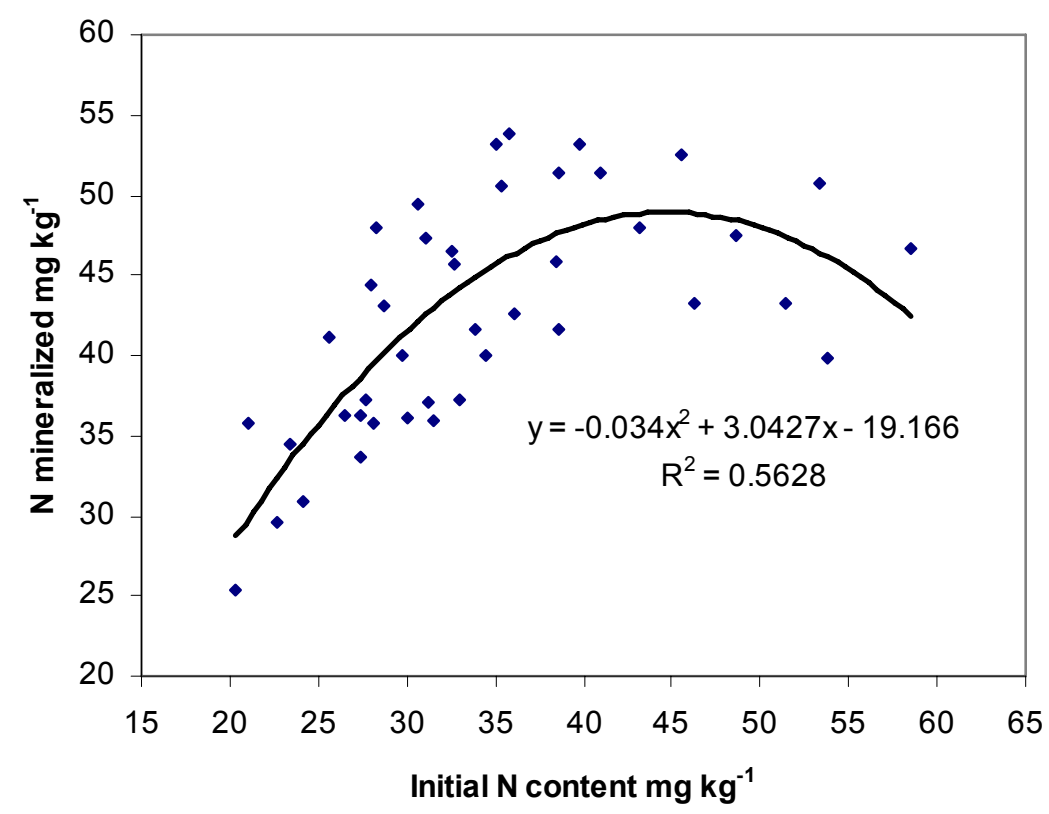

Figure 3. Relationship between initial nitrogen content and mineralization 
The best fit equations for cumulative $\mathrm{N}$ mineralization in different treatments were derived and given in Table 2 . The results indicated that $2^{\text {nd }}$ order polynomial function fits better than logarithmic or linear model under island condition. In general, the model results had indicated that the cumulative mineralized $\mathrm{N}$ was the function of initial $\mathrm{N}$ content, type of materials and the presence of nitrification inhibitors. It was also seen that the $\mathrm{R}^{2}$ value was high $\left(\mathrm{R}^{2}>0.85\right)$ for all the treatments. Odhiambo (2010) also reported similar such reports from his study on nitrogen release by green manure in different soil types.

Table 1. Effect of different treatments on mineral nitrogen content

\begin{tabular}{|c|c|c|c|c|c|c|c|c|c|}
\hline \multirow{2}{*}{ Treatments } & \multicolumn{3}{|c|}{$\begin{array}{l}\text { Initial N } \\
\left(\mathrm{mg} \mathrm{kg}^{-1}\right)\end{array}$} & \multicolumn{3}{|c|}{$\begin{array}{l}\text { N Mineralized at } 104 \\
\text { DAI }\left(\mathrm{mg} \mathrm{kg}^{-1}\right)\end{array}$} & \multicolumn{3}{|c|}{$\begin{array}{l}\text { Total Mineral N } \\
\left(\mathrm{mg} \mathrm{kg}^{-1}\right)\end{array}$} \\
\hline & $\mathrm{NO}_{3}^{-}$ & $\mathrm{NH}_{4}^{+}$ & Total & $\mathrm{NO}_{3}^{-}$ & $\mathrm{NH}_{4}^{+}$ & Total & $\mathrm{NO}_{3}^{-}$ & $\mathrm{NH}_{4}^{+}$ & Total \\
\hline Control & 19.76 & 3.74 & 23.50 & 17.44 & 12.91 & 30.35 & 37.20 & 16.7 & 53.85 \\
\hline $120 \mathrm{~kg} \mathrm{~N} \mathrm{ha}^{-1}$ through V.C & 9.13 & 5.51 & 34.64 & 21.29 & 17.84 & 39.13 & 50.42 & 23.3 & 73.77 \\
\hline $90 \mathrm{~kg} \mathrm{~N} \mathrm{ha}^{-1}$ through V.C & 7.16 & 3.64 & 30.80 & 22.09 & 14.74 & 36.83 & 49.25 & 18.4 & 67.63 \\
\hline $60 \mathrm{~kg} \mathrm{~N} \mathrm{ha}^{-1}$ through V.C & 20.47 & 3.69 & 24.16 & 23.64 & 11.67 & 35.31 & 44.11 & 15.4 & 59.47 \\
\hline $120 \mathrm{~kg} \mathrm{~N} \mathrm{ha}^{-1}$ through V.C+P.M & 36.06 & 5.64 & 41.70 & 41.19 & 10.98 & 52.17 & 77.26 & 16.6 & 93.87 \\
\hline $90 \mathrm{~kg} \mathrm{~N} \mathrm{ha}^{-1}$ through V.C $+\mathrm{P}$ & 27. & 4.00 & 31.40 & 37.55 & 12.63 & 50.18 & 64.94 & 16.6 & 81.58 \\
\hline $60 \mathrm{~kg} \mathrm{~N} \mathrm{ha}^{-1}$ through V.C + P.M & 27.17 & 3.33 & 30.50 & 24.42 & 13.02 & 37.44 & 51.59 & 16.4 & 67.94 \\
\hline $120 \mathrm{~kg} \mathrm{~N} \mathrm{ha}^{-1}$ through I.O & 22.68 & 13.16 & 35.84 & 24.01 & 26.66 & 50.67 & 46.69 & 39.8 & 86.51 \\
\hline $60 \mathrm{~kg} \mathrm{~N} \mathrm{ha}^{-1}$ through I.O & 24.64 & 7.28 & 31.92 & 23.97 & 24.07 & 48.04 & 48.61 & 31.4 & 79.96 \\
\hline $120 \mathrm{~kg} \mathrm{~N} \mathrm{ha}^{-1}$ through V.C + I.O & 39.47 & 9.93 & 49.40 & 25.66 & 22.61 & 48.27 & 65.13 & 32.5 & 97.67 \\
\hline $90 \mathrm{~kg} \mathrm{~N} \mathrm{ha}^{-1}$ through V.C+I.O & 31.90 & 7.30 & 39.20 & 22.21 & 23.26 & 45.47 & 54.10 & 30.6 & 84.67 \\
\hline $60 \mathrm{~kg} \mathrm{~N} \mathrm{ha}^{-1}$ through V.C+I.O & 23.37 & 5.33 & 28.70 & 23.47 & 20.49 & 43.96 & 46.84 & 25.8 & 72.66 \\
\hline $120 \mathrm{~kg} \mathrm{~N} \mathrm{ha}^{-1}$ through V.C $+\mathrm{Neem}$ & 39.76 & 10.36 & 54.60 & 18.73 & 23.83 & 42.54 & 52.47 & 38.2 & 90.66 \\
\hline $60 \mathrm{~kg} \mathrm{~N}$ ha $^{-1}$ through V.C + Neem & 22.14 & 5.12 & 27.26 & 15.24 & 18.53 & 33.77 & 37.38 & 23.7 & 61.03 \\
\hline CD (0.05) & 4.56 & 1.46 & 5.99 & 4.56 & 4.56 & 6.25 & 7.64 & 5.58 & 11.36 \\
\hline
\end{tabular}

Table 2. Best fit $\mathrm{N}$ mineralization prediction equations for different treatments

\begin{tabular}{lllll}
\hline Treatments & Log equations & $\mathrm{R}^{2}$ & Polynomial equations & $\mathrm{R}^{L}$ \\
\hline Control & $\mathrm{y}=12.163 \operatorname{Ln}(\mathrm{x})-0.0115$ & $0.971 \mathrm{y}=-0.1779 \mathrm{x} 2+4.8626 \mathrm{x}-1.6497$ & 0.999 \\
$120 \mathrm{~kg} \mathrm{~N} \mathrm{ha}^{-1}$ through V.C & $\mathrm{y}=15.654 \operatorname{Ln}(\mathrm{x})-0.8075$ & $0.960 \mathrm{y}=-0.1755 \mathrm{x} 2+5.6606 \mathrm{x}-1.7898$ & 0.999 \\
$90 \mathrm{~kg} \mathrm{~N} \mathrm{ha}^{-1}$ through V.C & $\mathrm{y}=14.739 \operatorname{Ln}(\mathrm{x})-1.1888$ & $0.951 \mathrm{y}=-0.137 \mathrm{x} 2+5.0161 \mathrm{x}-1.5327$ & 0.999 \\
$60 \mathrm{~kg} \mathrm{~N} \mathrm{ha}^{-1}$ through V.C & $\mathrm{y}=14.235 \operatorname{Ln}(\mathrm{x})-1.4769$ & $0.948 \mathrm{y}=-0.1273 \times 2+4.7907 \mathrm{x}-1.7167$ & 0.999 \\
$120 \mathrm{~kg} \mathrm{~N} \mathrm{ha}^{-1}$ through V.C+P.M & $\mathrm{y}=18.333 \operatorname{Ln}(\mathrm{x})+7.0207$ & $0.978 \mathrm{y}=-0.2981 \mathrm{x} 2+7.6555 \mathrm{x}+3.968$ & 0.999 \\
$90 \mathrm{~kg} \mathrm{~N} \mathrm{ha}^{-1}$ through V.C+P.M & $\mathrm{y}=19.384 \operatorname{Ln}(\mathrm{x})+2.7848$ & $0.974 \mathrm{y}=-0.342 \mathrm{x} 2+8.4051 \mathrm{x}-1.0724$ & 0.997 \\
$60 \mathrm{~kg} \mathrm{~N} \mathrm{ha}^{-1}$ through V.C+P.M & $\mathrm{y}=14.422 \operatorname{Ln}(\mathrm{x})+0.7812$ & $0.961 \mathrm{y}=-0.1622 \mathrm{x} 2+5.2199 \mathrm{x}-0.12870 .999$ \\
$120 \mathrm{~kg} \mathrm{~N} \mathrm{ha}^{-1}$ through I.O & $\mathrm{y}=16.896 \operatorname{Ln}(\mathrm{x})+11.011$ & $0.995 \mathrm{y}=-0.4319 \mathrm{x} 2+8.734 \mathrm{x}+5.3589$ & 0.972 \\
$60 \mathrm{~kg} \mathrm{~N} \mathrm{ha}^{-1}$ through I.O & $\mathrm{y}=16.882 \operatorname{Ln}(\mathrm{x})+6.8329$ & $0.993 \mathrm{y}=-0.3159 \mathrm{x} 2+7.4698 \mathrm{x}+3.407$ & 0.988 \\
$120 \mathrm{~kg} \mathrm{~N} \mathrm{ha}^{-1}$ through V.C+ I.O & $\mathrm{y}=17.67 \operatorname{Ln}(\mathrm{x})+5.3845$ & $0.993 \mathrm{y}=-0.3585 \mathrm{x} 2+8.1414 \mathrm{x}+1.139$ & 0.992 \\
$90 \mathrm{~kg} \mathrm{~N} \mathrm{ha}^{-1}$ through V.C+I.O & $\mathrm{y}=16.94 \operatorname{Ln}(\mathrm{x})+3.4798$ & $0.987 \mathrm{y}=-0.2827 \mathrm{x} 2+7.1316 \mathrm{x}+0.647$ & 0.995 \\
$60 \mathrm{~kg} \mathrm{~N} \mathrm{ha}^{-1}$ through V.C+I.O & $\mathrm{y}=16.316 \operatorname{Ln}(\mathrm{x})+3.3776$ & $0.982 \mathrm{y}=-0.2503 \mathrm{x} 2+6.6304 \mathrm{x}+1.070$ & 0.997 \\
$120 \mathrm{~kg} \mathrm{~N} h a^{-1}$ through V.C+Neem $\mathrm{y}=16.743 \operatorname{Ln}(\mathrm{x})-0.3787$ & $0.968 \mathrm{y}=-0.2431 \mathrm{x} 2+6.677 \mathrm{x}-2.6197$ & 0.998 \\
$60 \mathrm{~kg} \mathrm{~N} \mathrm{ha}^{-1}$ through V.C+Neem & $\mathrm{y}=13.627 \operatorname{Ln}(\mathrm{x})-1.5433$ & $0.941 \mathrm{y}=-0.1104 \mathrm{x} 2+4.4654 \mathrm{x}-1.5724$ & 0.999 \\
\hline
\end{tabular}




\subsection{Soil $p H$}

In general, upon addition of organic manures a slight increase in soil $\mathrm{pH}$ was observed except inorganic fertilizer addition till 15th days after incubation (Figure 4) but it significantly differed only from $30^{\text {th }}$ days onwards $(\mathrm{p}<0.05)$. Among the treatments V.C+P.M recorded higher $\mathrm{pH}$ (6.28) followed by V.C+Neem (6.24), V.C (6.20) and I.O+V.C (6.17) at the same time inorganic fertilizer resulted in low $\mathrm{pH}$ (5.73). The effect decreased after 90 days after incubation and at the end of 120 days soil $\mathrm{pH}$ did not differ significantly except for V.C+P.M (T5). In contrast to the effect of organic manures, inorganic fertilizer resulted in lowering of soil $\mathrm{pH}$ though it was non-significant at the end of incubation period.

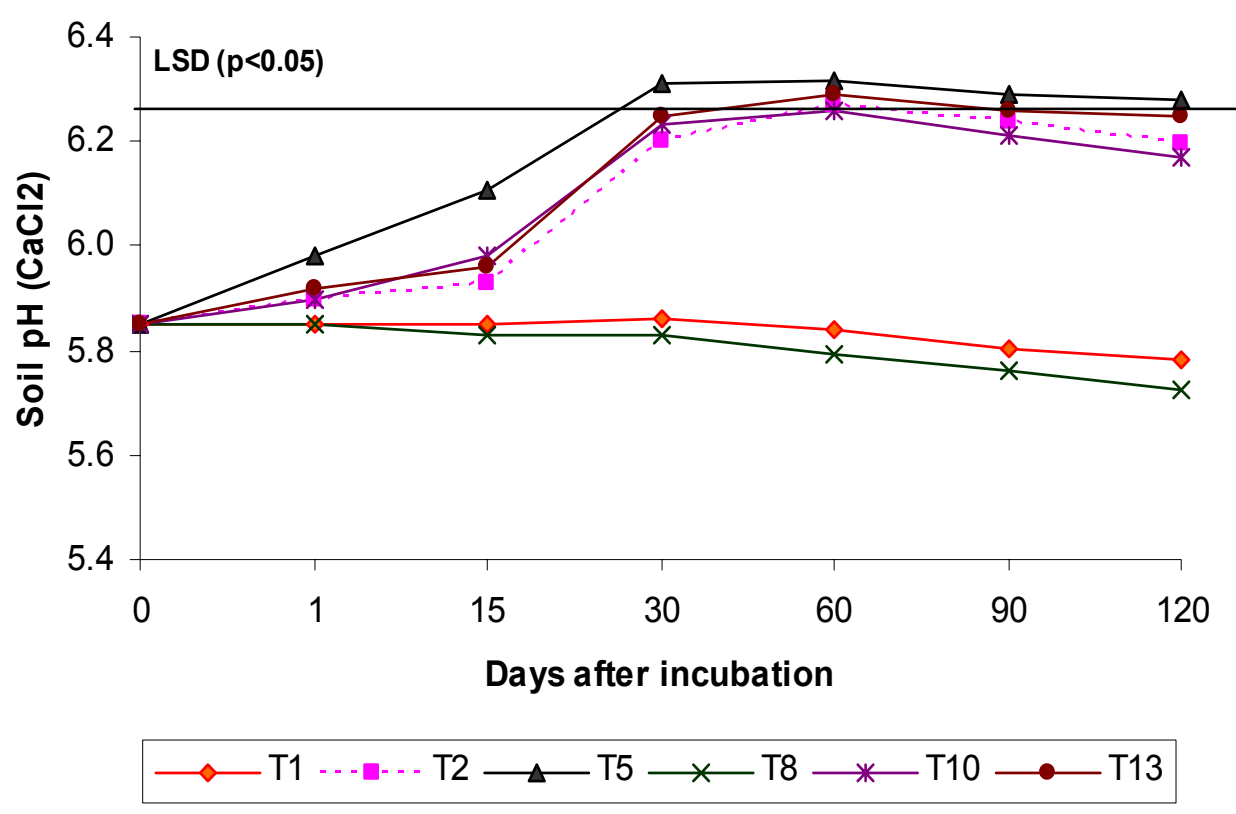

Figure 4. Changes in soil $\mathrm{pH}$ during mineralization

\section{Discussion}

Under the conditions of the investigations, immediately after the addition of manures and fertilizers an increase in the concentration of $\mathrm{NH}_{4}{ }^{+}-\mathrm{N}$ was observed. This rapid rise of $\mathrm{NH}_{4}{ }^{+}-\mathrm{N}$ content is attributable to the decomposition of the easily decomposable nitrogenous substances present in the organic materials. This is in corroboration with the results of Nagarajah (1988) and Gonzalex Priesto, Carballas, Villar, and Carballas (1995). This process is brought about by microorganisms present under various soil and climatic conditions (Power, 1962; Godlin \& Olinevich, 1966) and also under anaerobic conditions (Morgham \& Ayotade, 1968). Whereas the decrease in $\mathrm{NH}_{4}{ }^{+} \mathrm{N}$ than control as observed in some of the treatments (T3, T4, and T7) indicated the utilization of $\mathrm{NH}_{4}{ }^{+}$by soil microorganisms or by volatilization losses (Iritani \& Arnold, 1960). Also, nitrification brings about a decrease in the concentration of $\mathrm{NH}_{4}{ }^{+}-\mathrm{N}$. Similarly increase in the concentration of $\mathrm{NO}_{3}{ }^{2-} \mathrm{N}$ was observed in several treatments two days after the incubation as a result of the activity of nitrifying bacteria which converts $\mathrm{NH}_{4}{ }^{+}-\mathrm{N}$ into $\mathrm{NO}_{3}{ }^{2-} \mathrm{N}$. As a result of rise in $\mathrm{NH}_{4}{ }^{+}-\mathrm{N}$ or $\mathrm{NO}_{3}{ }^{2-} \mathrm{N}$ or both the total available nitrogen has increased.

It was observed from the study that the amount of $\mathrm{NH}_{4}{ }^{+}$and $\mathrm{NO}_{3}{ }^{2-} \mathrm{N}$ mineralized significantly differed among the treatments. At the end of the incubation period the highest total $\mathrm{NH}_{4}{ }^{+}$nitrogen $\left(39.8 \mathrm{mg} \mathrm{kg}^{-1}\right)$ was observed in inorganic fertilizer than V.C, P.M and neem treatments. This was due to the fact that application of inorganic fertilizer narrows down the $\mathrm{C} / \mathrm{N}$ ratio of the soil resulting in higher net $\mathrm{N}$ mineralization (Patil, 1990). This indicated a lower rate of nitrification in soils not supplied with any organic materials which may results in ammonia volatilization losses. This was evidenced from the fact that higher $\mathrm{NO}_{3}{ }^{2-}$ content of $82.3 \%$ to total available $\mathrm{N}$ observed for V.C+P.M treatment. This implies the presence of an easily mineralizable $\mathrm{N}$ pool in the manure usually related to less stable organic matter (Laos, Satti, Walter, \& Mazzarino, 2000; Preusch, Adler, Sikora, \& Tworkoski, 2002). 
Neem acting as a nitrification inhibitor when mixed with inorganic fertilizers was widely reported (Santhi et al., 1986; Suganya et al., 2007; Gnanavelrajah, 2011). In the present study it was observed that the $\mathrm{NO}_{3}{ }^{2-} \mathrm{N}$ content remains significantly lower than the control in $\mathrm{VC}+$ Neem treatment during the initial 10 days indicating that nitrification has been inhibited. A large number of organic compounds are known to inhibit nitrification (Iritani \& Arnold, 1960) and it is likely that one or more of these compounds were released during decomposition of neem cake. The $\mathrm{NO}_{3}{ }^{2-} \mathrm{N}$ production in V.C + Neem mixture has rapidly increased after the $5^{\text {th }}$ week of incubation (Table 3) indicating that the nitrification inhibitory effect has disappeared after this stage probably due to the decomposition of the inhibitory compound or due to adaptation of nitrifying organisms to the inhibitor. Decomposition of nitrification inhibitors have been shown by Redemann, Martin, Wein, and Widofsky (1965), while Debona and Audus (1970) have reported adaptation of nitrifying organisms to nitrification inhibitors. Thus application of V.C mixed with neem resulted in slower availability of nitrogen but for longer duration and increased $\mathrm{N}$ use efficiency under island conditions.

Increased rate of application of $\mathrm{N}$ fertilizers and its equivalent organic manures resulted in increased $\mathrm{N}$ mineralization which was also reported by Woods, Cole, Porter and Coleman (1987) and Patil and Sarkar (1993). However, lower available $\mathrm{N}$ among different treatments receiving same rate of manures and inorganic fertilizer was due to the gaseous losses of nitrogen. The results further indicated that at $120 \mathrm{~kg} \mathrm{~N}$ equivalent ha ${ }^{-1}$ the total mineral N (initial $+\mathrm{N}$ mineralized) was highest in I.O+V.C followed by V.C+P.M $>$ I.O $>$ P.M $>$ control. The low total mineral $\mathrm{N}$ of inorganic was possibly due to volatilization losses of $\mathrm{N}$ in the form of ammonia from inorganic fertilizer. On the other hand higher mineral $\mathrm{N}$ of $\mathrm{IO}+\mathrm{VC}$ were due to favorable soil environment. It is to be noted that $\mathrm{VC}+\mathrm{PM}$ can supply upto $208 \mathrm{~kg} \mathrm{ha}^{-1}$ of mineral $\mathrm{N}$ which is one par with inorganic and $\mathrm{IO}+\mathrm{VC}$, if managed properly this could be best option of nutrient supply for vegetable crops.

The observed increase in soil $\mathrm{pH}$ could be due to proton $\left(\mathrm{H}^{+}\right)$transfer from soil to the organic materials which is mainly governed by initial soil $\mathrm{pH}$ and the nature of organic materials (Marschner \& Noble, 2000). The differences among organic amendments could be due to the release of base cations especially $\mathrm{Ca}$ and $\mathrm{Mg}$ which resulted in acid neutralization during microbial decarboxylation (Tang \& Yu, 1999). In the present study the neutralizing effect of P.M was due to the presence of substantial quantity $(2.49 \%)$ of calcium which resulted in significant improvement in soil $\mathrm{pH}$. Thus, organic manures acted as an amendment to acid soils which might have improved the $\mathrm{N}$ mineralization.

\section{Conclusions}

The study indicated that manures and inorganic fertilizer increases the mineral nitrogen at different rate and the period of availability varies. Although the mineralization of nutrients from vermicompost, poultry manure is slower than the inorganic fertilizer, the period of availability is longer thereby the loss of nutrients into the environment can be reduced. Similarly V.C mixed with neem resulted in slower availability of nitrogen for longer duration. Thus the nutrient use efficiency of manures was increased and it can be a best organic source to supply nitrogen to the plant for a longer period of time.

\section{References}

Amanullah, M. M. (2007). N release pattern in poultry manured soil. Journal of Applied Sciences Research, 3(10), 1094-1096.

Atiyeh, R. M., Subler, S., Edwards, C. A., Bachman, G., Metzger, J. D., \& Shuster, W. (2000). Effects of vermicomposts and compost on plant growth in horticultural container media and soil. Pedobiologia, 44, 579 -590. http://dx.doi.org/10.1078/S0031-4056(04)70073-6

Bairwa, (2009). Response of integrated nutrient management on yield, quality and physico-chemical characteristics of okra. Indian Journal of Horticulture, 66(3), 310-314.

Banik, P., Ghosal, P. K., Sasmal, T. K., Bhattacharya, S., Sarkar, B. K., \& Bagchi, D. K. (2006). Effect of Organic and Inorganic Nutrients for Soil Quality Conservation and Yield of Rainfed Low Land Rice in Sub-tropical Plateau Region. Journal of Agronomy and Crop Science, 192(5), 331-343. http://dx.doi.org/10.1111/j.1439-037X.2006.00219.x

Bartholomow, W. W. (1965). Mineralization and immobilization of nitrogen in the decomposition of plant and animal residues. In W. W. Bartholomow, \& F. E. Clark (Eds.) Soil Nitrogen (pp. 285-306). Madison, Wisconsin: American Society of Agronomy.

Buckerfield, J. C., \& Webster, K. A. (1998). Worm-worked waste boosts grape yields: Prospects for vermicompost use in vineyards. The Australian and New Zealand Wine Industry Journal, 13, 73-76. 
Debona, A. C., \& Audus, L. J. (1970). Studies on the effects of herbicides on soil nitrification. Weed Research, 10, 250-263. http://dx.doi.org/10.1111/j.1365-3180.1970.tb00949.x

DES. (2009). Statistical hand book, Directorate of Economics and Statistics, Government of Andaman and Nicobar islands, Port Blair, India. Retrieved from http://agri.and.nic.in/area_production.htm

Doran, J. W., \& Parkin, T. B. (1994). Defining and assessing soil quality. In J. W. Doran (Eds.), Defining soil quality for a sustainable environment (pp. 3-21). SSSA Special Publication No: 35, Madison, WI.

Ganeshamurthy, A. N., Dinesh, R., Ravisankar, N., Nair, A. K., \& Ahlawat, S. P. S. (2002). Land resources of Andaman and Nicobar Islands, Central Agricultural Research Institute, Port Blair, India.

Gnanavelrajah, N. (2011). Blending Urea with Organic Materials Possessing Antimicrobial Property on Nitrification and Ammonia Volatilization in a Tropical Soil. World Journal of Agricultural Sciences, 7(6), 705-709. Retrieved from http://idosi.org/wjas/wjas7(6)/11.pdf

Godlin, M. M., \& Olinevich, V. A. (1966). Dynamics of mobile forms of nitrogen, phosphorus and potassium in peat soils utilized for different lengths of time. Agrokhimiya, 2, 22-37.

Gonzalex Priesto, S. J., Carballas, M., Villar, M. C., \& Carballas, T. (1995). Organic nitrogen mineralization in temperate humid zone soils after two and six weeks of aerobic incubation. Biology and Fertility of Soils, 20, 237-242. http://dx.doi.org/10.1007/BF00336083

Iritani, W. M., \& Arnold, C. Y. (1960). Nitrogen release of vegetable crop residues during incubation as related to their chemical composition. Soil Science, 89, 74-82. http://dx.doi.org/10.1097/00010694-196002000-00002

Islam, M. M., Karim, A. J. M. S, Jahiruddin, M., Majid, N. M., Miah, M. G., Ahmed, M. M., \& Hakin, M. A. (2011). Effects of organic manure and chemical fertilizers on crops in the radish-stem amaranth-Indian spinach cropping pattern in homestead area. Australian Journal of Crop Science, 5(11), 1370-1378.

Jackson, M. L. (1973). Soil chemical analysis (pp. 339-69), Prentice Hall of India Private Limited, New Delhi.

Kumar, M., Narase Gowda, N. C., Raviraja Shetty, G., \& Karthik, M. N. (2011). Effect of organic manures and inorganic fertilizers on available NPK, microbial density of soil and nutrient uptake of Brinjal. Research Journal of Agricultural Sciences, 2(2), 304-307.

Laos, F., Satti, P., Walter, I., \& Mazzarino, M. J. (2000). Nutrient availability of composted and noncomopsted residues in a Patagonian Xeric Mollison. Biology and Fertility of Soils, 31, 462-469. http://dx.doi.org/10.1007/s003740000192

Larson, W. E. \& Clapp, C. E. (1984). Effects of organic matter on soil physical properties. In Organic Matter and Rice. Philippines, International Rice Research Institute. Retrieved from http://pdf.usaid.gov/pdf_docs/PNAAR182.pdf

Manna, M. C., Ghosh, P. K., \& Acharya, C. L. (2003). Sustainable crop production through management of soil organic carbon in semiarid and tropical India. Journal of Sustainable Agriculture, 21(3), 85-114. http://dx.doi.org/10.1300/J064v21n03_07

Marschner, B., \& Noble, A. D. (2000). Chemical and biological processes leading to the neutralization of acidity in soil incubated with litter materials. Soil Biology and Biochemistry, 32, 805-813. http://dx.doi.org/10.1016/S0038-0717(99)00209-6

Martin, B., \& Venterea. R. T. (2007). Nitrogen immobilization and mineralization kinetics of cattle, hog and turkey manure applied to soil. Soil Science Society of America Journal, 72, 1570-1579.

Masciandaro, G., Ceccanti, B., \& Garcia, C., (1997). Soil agro-ecological management: Fertigation and $\begin{array}{llll}\text { vermicompost } \quad \text { treatments. } & \text { Bioresource } & \text { Technology, } & 59,\end{array}$ http://dx.doi.org/10.1016/S0960-8524(96)00142-3

Nagarajah, S. (1988). Transformation of green manure nitrogen in lowland rice soils. In: Green Manure in Rice Farming. IRRI, Philippines (pp.193-209).

Odhiambo, J. J. O. (2010). Decomposition and nitrogen release by green manure legume residues in different soil types. African Journal of Agricultural Research, 5(1), 90-96.

Pathak, H. \& Sarkar, M.C. (1994). N supplying capacity of an Ustochrept amended with manures, urea and their combinations. Journal of Indian Society of Soil Science, 42, 261-267.

Patil, R.G. (1990). Mineralization-Immobilization of nitrogen as influenced by green manure and urea in straw amended soils. Ph.D., Thesis, IARI, New Delhi. 
Patil, R. G., \& Sarkar, M. C. (1993). Mineralization and Immobilization of N in soil mixed with wheat straw. Journal of Indian Society of Soil Science, 41, 33-37.

Power, J. F. (1962). Mineralization of nitrogen in grass roots. Proceedings of Soil Science Society of America, 32, 673-674. http://dx.doi.org/10.2136/sssaj1968.03615995003200050027x

Power, J. F., \& Papendick, R. I. (1985). Organic sources of nitrogen. In O. P. Engelstad (Ed.), Fertilizer Technology and Use (pp. 503-520). Soil Science Society of America. Madison, Wisconsin, USA.

Preusch, P. L., Adler, P. R., Sikora, I. J. \& Tworkoski, T. J. (2002). Nitrogen and phosphorus availability in composted and uncomposted poultry manure litter. Journal of Environmental Quality, 31, 2051-2057. http://dx.doi.org/10.2134/jeq2002.2051

Rayar, A. A. (1984). Physio-chemical properties of semi arid soils incubated with different sources of organic manures. Madras Agricultural Journal, 71, 43-47.

Redemann, C. T., Martin, R. T., Wein, J. D., \& Widofsky, J. G. (1965). Tracer study of residues from 2-chloro-6(trichloromethyl) pyridine in plants. Journal of Agricultural and Food Chemistry, 13, 518-521. http://dx.doi.org/10.1021/jf60142a009

Santhi, S. R., Palaniappan, S. P., \&. Purushothaman, D. L. (1986). Influence of neem leaf on nitrification in a low land rice soil. Plant and Soil, 93, 133-136. http://dx.doi.org/10.1007/BF02377153

SAS (2001). SAS Procedures Guide, Version 8. SAS Institute Inc., Cary, NC, USA. Retrieved from http://www.ats.ucla.edu/stat/sas/v8/stat_ce.pdf

Siavoshi, M., Nasiri, A., \& Laware, S. L. (2011). Effect of organic fertilizer on growth and yield component in rice. Journal of Agricultural Science, 3(3), 217-224.

Sudha, B., \& Chandini, S. (2003). Vermicompost - potential organic manure for rice. Intensive Agriculture, no page (Check)

Suganya, S., Appavu, K., \& Vadivel, A. (2007). Nitrogen release pattern of neem coated urea products in flood water. An Asian Journal of Soil Science, 2(2), 128-133. Retrieved from http://www.connectjournals.com/file_html_pdf/656302H_128-133

Tang, C., \& Yu, Q. (1999). Impact of chemical composition of legume residues and initial soil $\mathrm{pH}$ on $\mathrm{pH}$ change of a soil after residue incorporation. Plant and Soil, 215, 29-38. http://dx.doi.org/10.1023/A:1004704018912

Weeraratna, C. S. (1979). Pattern of nitrogen release during decomposition of some green manures in a tropical alluvial soil. Plant and Soil, 53, 287-294.

Woods, L. E., Cole, C. V., Porter, L. K., \& Coleman, D. C. (1987). Transformation of added and indigenous nitrogen in gnotobiotic soil. Soil Biology and Biochemistry, 19, 673-678. http://dx.doi.org/10.1016/0038-0717(87)90046-0

Yadvinder S., Bijay, S., \& Khind, C. S. (1992). Nutrient transformations in soils amended with green manures. Advances in Soil Science, 20, 237-309. http://dx.doi.org/10.1007/978-1-4612-2930-8_5 